\title{
Evaluation of Learner vs. Teacher Centered Syllabi in Construction Management Courses: An Initial Investigation
}

\author{
Ben Farrow ${ }^{1}$, Tom Leathem ${ }^{1}$, Amna Salman ${ }^{1}$ \\ ${ }^{1}$ McWhorter School of Building Science, Auburn University, Auburn, Alabama \\ Correspondence: Ben Farrow, McWhorter School of Building Science, 118 Miller Gorrie Center, Auburn University, \\ Auburn, Alabama 36849, USA.
}

Received: November 10, 2021

Accepted: December 13, 2021

Online Published: December 15, 2021

doi:10.11114/ijce.v5i1.5403

URL: https://doi.org/10.11114/ijce.v5i1.5403

\begin{abstract}
Research indicates that retention and performance of undergraduate students increases when they perceive a cooperative and supportive educational community. The course syllabus is one of the first opportunities to influence student perception on their educational experience. Literature on syllabi suggests that learner-centered syllabi yield more positive student perceptions of teachers and the course as compared to traditional teacher-centered syllabi. Current research on the impacts of different syllabi constructs within construction education is lacking, and no studies could be found on whether these perceptions translate to student grades. This study used action research to better understand the impact of a learnercentered syllabus vs. a teacher-centered syllabus in an undergraduate construction management program. Student perception, faculty perception and student grades were measured between the learner-centered class and the teachercentered class. The data was collected from four different classes, split among two courses, and taught by two faculty over the spring 2020 semester. Results suggested that the learner-centered syllabi appeared to motivate student engagement as well as impact both, the first impressions of the instructor and teacher-student relationship. However, it showed no difference in student grades.
\end{abstract}

Keywords: syllabi, learner-centered, teacher-centered, outcomes

\section{Introduction}

\subsection{The Problem}

Research in a variety of disciplines indicates that undergraduate students are retained at a higher rate and perform at higher academic levels when they perceive they belong to a cooperative and supportive education community (Kuh, 2009; Tinto, 2006; Zhao \& Kuh, 2004). The construction management program at Auburn University understands this and attempts to support students to this end in a variety of ways: first-year experience seminars, professional advising, early alert grade notices, small class sizes, a lock-step program with a single peer group starting in the junior year, an open-door faculty policy, and a senior thesis project. For many of these students, their first experience where they recognize this supportive educational community comes through the faculty in a construction management classroom.

On the first day of every construction management class, the syllabus is distributed to students per university requirements. The syllabus is defined by Merriam-Webster (n.d.) as, "a summary outline of a discourse, treatise, or course of study or of examination requirements". The Chronicle of Higher Education specifically notes that it is the instructor's opportunity for a "first impression" (Gannon, n.d.). The syllabus for construction management courses often conveys learning objectives, grading requirements, and basic logistics of a course. In addition, it identifies grading criteria, important deadlines, and student penalties if policies are not followed. These syllabus elements set the expectation for student engagement in a community of learners. In essence, the syllabus conveys a professor's approach to teaching and learning as well as the attitude toward students and course conceptualization. Broader educational research has focused on syllabi that enhance student engagement. These syllabi are known as "learner-centered" (Richmond et al., 2019; Weimer, 2002). Such syllabi are characterized by the following items (Wheeler et al., 2019):

- Engaging, question-driven course description

- Long-ranging, multi-faceted learning goals

- Clear, measurable learning objectives 
- Robust assessment and activity descriptions

- Detailed course schedule

- Inviting, approachable, and motivating tone

- Focus on student success

"The style and design of a syllabus can set an impression of an instructor and the course. These impressions can serve as an anchor for the tone of the course." (Lightner \& Benander, 2018, p. 443) For a construction management program that already supports students academically through a broad array of activities, the researchers questioned if further shifts in syllabi toward a learner-centered approach would impact student performance in the class. Could more learner-centered syllabi set expectations for the class that enhance student engagement and improve the student/teacher experience? Could incremental shifts in syllabi tools and processes lead to incremental improvement of student grades?

To conduct the study, the researchers adopted an action research approach. Action research is an established method for scholarly investigation that aims at testing theory within the context of investigating a problem in real setting. This method is a widely accepted approach for advancing teaching and learning because it is grounded in practical actions, aimed at solving realistic problems (Altrichter et al., 2002; Hjordis, 2018; John et al., 2015; Marlon et al., 2021; Zimmer \& Keiper, 2021). It is a five-phase cyclic process as shown in Figure 1. The developed research framework and steps were based on the five-phase cycle (Figure 2).

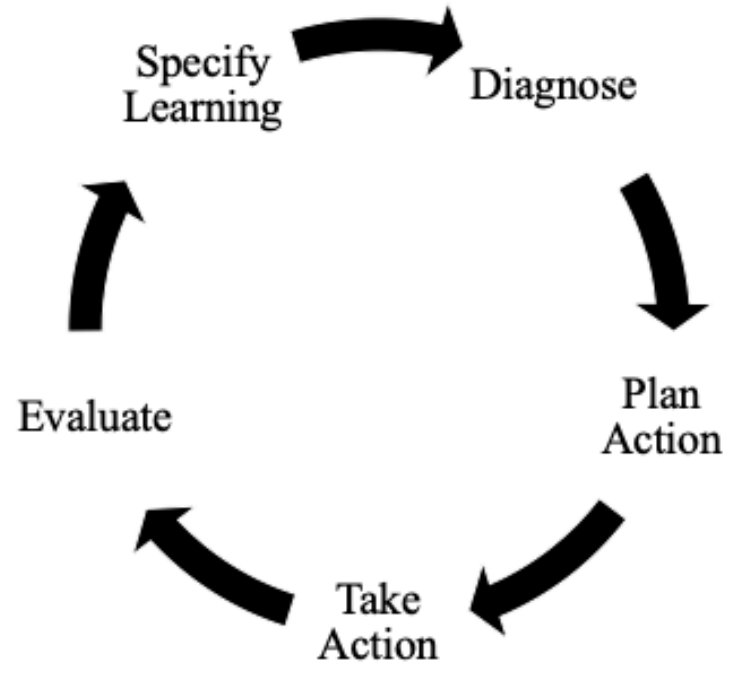

Figure 1. The Action Research Cycle (Adapted from Baskerville, 1999)

Syllabi for two different construction management courses were evaluated in this study. Each course included two sections. One of the sections served as the control group, using the standard syllabus from previous semesters of each course. The other course sections syllabi were modified to approach a learner-centered syllabus as measured by a syllabus rubric (Figure 4, which served as the experimental group). The research compared student and faculty perspectives of learnercentered syllabi and evaluated grades earned under the learner-centered syllabus vs. students in the non-modified syllabus classes. The purpose of this work was to inform construction management faculty regarding future choices for syllabi preparation. Through this introductory action-research study, future decisions regarding syllabi development can be considered, and additional discussion of learner-centered teaching may be motivated among construction faculty. 


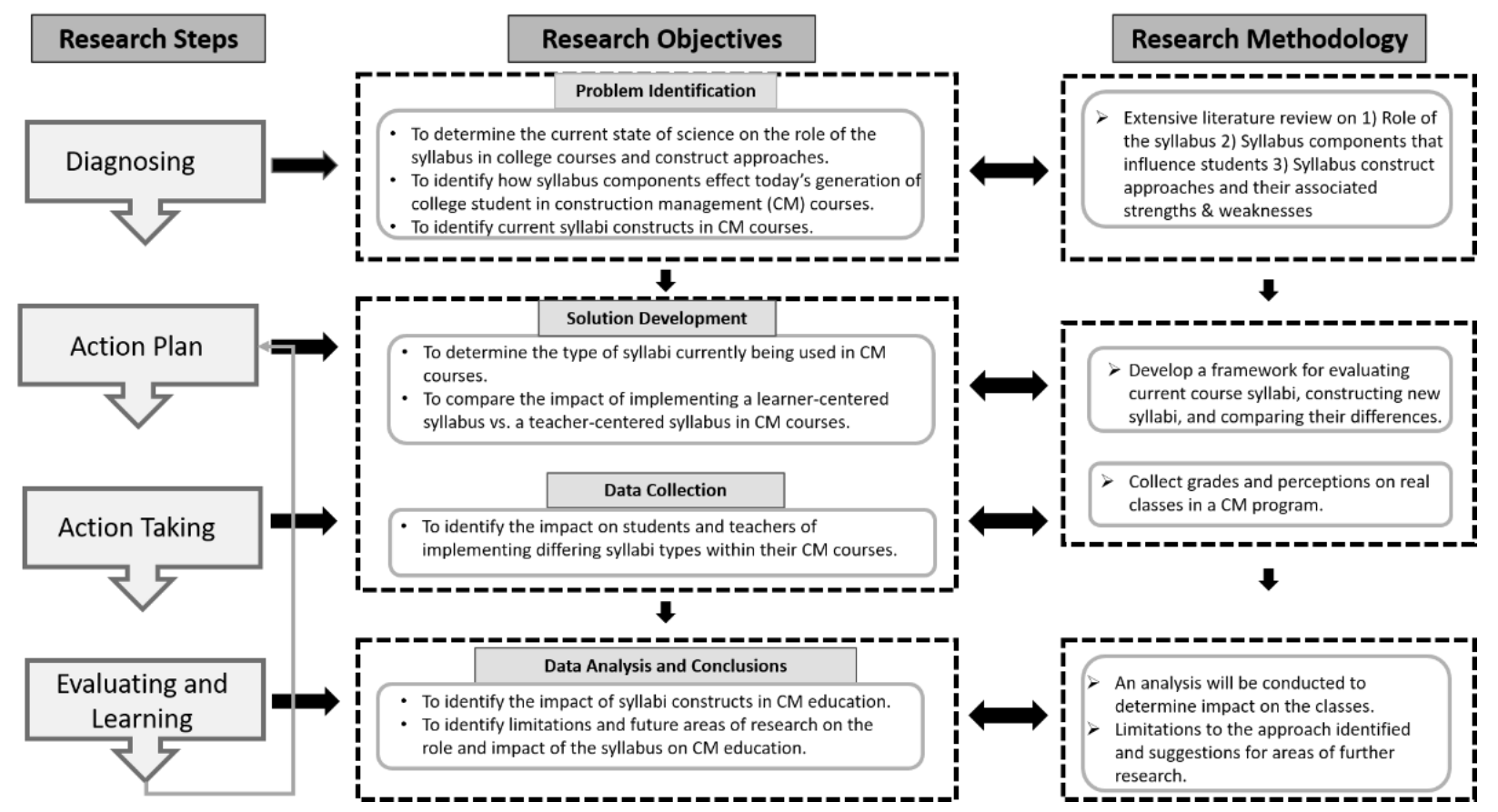

Figure 2. Research Framework

\subsection{Relevant Scholarship}

The syllabus is often the first item distributed, either a hard copy or in digital form, for most college courses and provides an opportunity to establish the tone for the class and the instructor (Lightner \& Benander, 2018). It is not only a courseplanning tool but also helps a student understand and anchor the instructor's goals and expectations. Studies indicate most faculty embrace the importance of the syllabus as it sets class policy and goals. Parkes and Harris (2002) suggest three key functions for a syllabus:

- Serve as a contract

- Serve as a permanent record

- Serve as an aid to student learning

Research shows that students prefer the following components of a syllabus (Lightner \& Benander, 2018):

- Contact information (front page, large font)

- Content organised (bold headers)

- Due dates (tables or lists)

- Length (3-5 pages with supplemental handouts as required)

- Neutral tone

- Policies (phrased positively)

Faculty tend to place more emphasis on the syllabus as a document that mediates the content of the course between the faculty member and the student. Students in turn view the syllabus as a reference document and expect course engagement to come directly from personal interaction within the class (Lightner \& Benander, 2018).

One research-based framework regarding the course content that recognized diversity of learners and sought to optimise teaching and learning for each individual student is Universal Design for Learning (UDL) (Burgstahler \& Cory, 2008). UDL focused on increasing and expanding the ways in which students were engaged, how information was represented, and how learning was expressed (Israel et al., 2014). By designing a syllabus using UDL principles, a platform could be set for improving the learning environment. Key UDL considerations in syllabi development included the following (Universal Design for Learning: A Rubric for Evaluating Your Course Syllabus, n.d.):

- Clear learning goals and objectives that engage students

- Clear expectations regarding schedule and routine

- Information provided in multiple formats (including technology) 
- Context and background information clarified

- Clarify timing and format of assessments

- Multiple resources for students (flexibility)

- Multiple ways to learn (flexibility)

- Engagement of various learning styles

- Examples of student work

- Objectives clearly linked to student assignments

At the University of Southern Maine, an effort was made to redesign course syllabi to incorporate UDL principles (Langley-Turnbaugh et al., 2013). The course used online tools to allow students to submit their work at convenient times outside of lecture. The lectures also engaged students in the learning process by using electronic clickers and quizzes that displayed the results immediately and allowed the instructor and the students to assess where they stand. Finally, the course used hands-on activities for promoting collaboration and teamwork. Results indicated improved faculty perceptions in the areas of student engagement, student feedback, and student self-sufficiency.

There is also a growing consensus that besides setting class policies and expectation, a syllabus also conveys the personality, creates a first impression of the instructor, and sets the tone for the rest of the semester. For example, Bain (2004) introduced the promising syllabus which focused on "beyond the classroom" learning. Such an approach shifted the course from "instructor-focused" to "learner-focused" and considered three primary components:

- "What this course promises you"

- "How will you fulfill these promises?"

- "Here begins a conversation about how the teacher and student will best come to understand the nature and progress of the student's learning."

Multiple researchers indicated that learner-centered syllabi yielded higher student evaluations of instructor, course, and syllabus, and set the stage for a high level of learning (Harnish \& Bridges, 2011; Richmond et al., 2016). The most important features of a learner-centered syllabus included assignment information, grading information, attendance information, and instructor contact information (Garavalia et al., 1999). Cullen and Harris (2009) developed a rubric to classify a syllabus as teacher-centered or learner-centered. The rubric had three main factors that are incorporated commonly into learner-centered syllabi: community, power and control, and evaluation and assessment.

Becker \& Calhoon (1999) found that students mostly focus on information regarding assignments, grading, attendance, and required work in a syllabus. This study also contradicted common faculty beliefs that students do not look at or read their syllabi, though they note that students may use the syllabus in ways faculty may not expect. Studies also indicate that student experience in the classroom became more meaningful if the syllabus promoted student involvement (Prior, 2018) in creating course policies (DiClementi \& Handelsman, 2005); presented greater detail about course assignment and grading requirements (Saville et al., 2010); and demonstrated concern for student learning (Richmond et al., 2016). Table 1 shows a summary of teacher-centered vs. the learner-centered syllabi elements.

Richmond et al (2016) used experimental design to compare student perception of teacher-centered vs. learner-centered syllabi. Ninety students were randomly assigned to either learner- or teacher-centered syllabi and provided their feedback on the syllabus assigned to them. The study found that faculty using a learner-centered syllabus were marked more positive, creative, enthusiastic, and caring. Beyond the perceptions of faculty, other researchers have found benefits for increased student empowerment (Ordem, 2021), happy and motivated students (Wilson \& Wilson, 2007), and better student instructor relationship (Richmond et al., 2016; Saville et al., 2010). 
Table 1. Summary of Teacher-Centered vs. Student-Centered Syllabus

\begin{tabular}{|c|c|c|}
\hline Syllabus Element & Teacher-Centered & Student-Centered \\
\hline $\begin{array}{l}\text { Professor Information (Name, } \\
\text { contact info, office hours) }\end{array}$ & $\begin{array}{l}\text { Transmitted from instructor } \\
\text { with limited options }\end{array}$ & $\begin{array}{l}\text { Multiple options with student } \\
\text { input }\end{array}$ \\
\hline $\begin{array}{c}\text { Course Information } \\
\text { (Description, location, texts, } \\
\text { topics, course calendar) }\end{array}$ & $\begin{array}{l}\text { Emphasizes teacher as } \\
\text { leader/authority with syllabus } \\
\text { as planning tool for instructor }\end{array}$ & $\begin{array}{c}\text { Presents teacher as } \\
\text { facilitator/partner in learning, } \\
\text { detailed assignment } \\
\text { information }\end{array}$ \\
\hline $\begin{array}{c}\text { Grading Information (policy, } \\
\text { scale, assignments) }\end{array}$ & $\begin{array}{c}\text { Focus on grades and } \\
\text { punishment }\end{array}$ & $\begin{array}{l}\text { Ongoing feedback, multiple } \\
\text { assessment approaches focused } \\
\text { on curiosity, student } \\
\text { autonomy, community }\end{array}$ \\
\hline $\begin{array}{l}\text { Policy Information } \\
\text { (attendance, late work, honor } \\
\text { code, disability) }\end{array}$ & $\begin{array}{l}\text { Fosters competitive, } \\
\text { individualistic approach }\end{array}$ & $\begin{array}{c}\text { Fosters collaborative, } \\
\text { supportive environment }\end{array}$ \\
\hline
\end{tabular}

\subsection{Relevance of the Research}

The existing literature has examined the perceived impact of two different styles of syllabus and compared the two styles; however, they lack the information of how students may contrast experiences in classes utilizing a learner-centered syllabus vs. a teacher-centered syllabus. Evaluation on the impact of student performance related to the two types of syllabi is also an area lacking previous research. This initial study attempts to address this gap by looking at how learnercentered vs. teacher-centered syllabi impact student perceptions and performance of students and teachers.

\section{Method}

As previous research suggests, the incorporation of learner-centered syllabi has the ability to create more student engagement in the class and facilitate a more positive student outlook of the class and the instructor (Langley-Turnbaugh et al., 2013). It would be reasonable to assume that these benefits would yield improvement in course grades over a more traditional teacher-centered syllabus. However, the authors found little research investigating the impact on grades between a teacher-centered vs. learner-centered syllabus approach. The researchers also determined through a previous study, that no learner-centered syllabi had been used in the program in which they teach. This was an interesting discovery, as the researchers would proport that much of the teaching in the program is learner-centered. Evidence of this includes the graduating senior surveys in the program which indicate over $75 \%$ of graduates citing the following learner-centered aspects: small class sizes; emphasis on career preparation and placement; dedicated senior thesis lab; strong faculty dedication and ability; emphasis on industry collaboration and connection; and engagement with technology. This represents a disconnect between the curriculum and pedagogy, causing one to question if syllabi construct has an effect if a learner-centered teaching approach is already in place. This research sought to investigate the impact on student grades, perception of the students on the class, and the perceptions of teachers when implementing a learner-centered syllabus. The research was guided by the following research questions:

- What were the student perceptions of the learner-centered class as opposed to the course that was more teachercentered?

- What were the faculty perceptions of the learner-centered class as opposed to the course that was more teachercentered?

- What differences may exist in grades from courses with learner-centered syllabi as opposed to courses with more teacher-centered syllabi?

\subsection{Research Approach}

To address the research questions, a quasi-experimental non-equivalent groups design using an action-research method was employed. This is a common type of design in action research when teachers want to evaluate new approaches to teaching where random assignment of participants is not possible (Frey, 2020). In the case of this study, the design intended to compare two sets of construction management courses in the spring 2020 semester that the researchers would be teaching (Figure 3 ). 


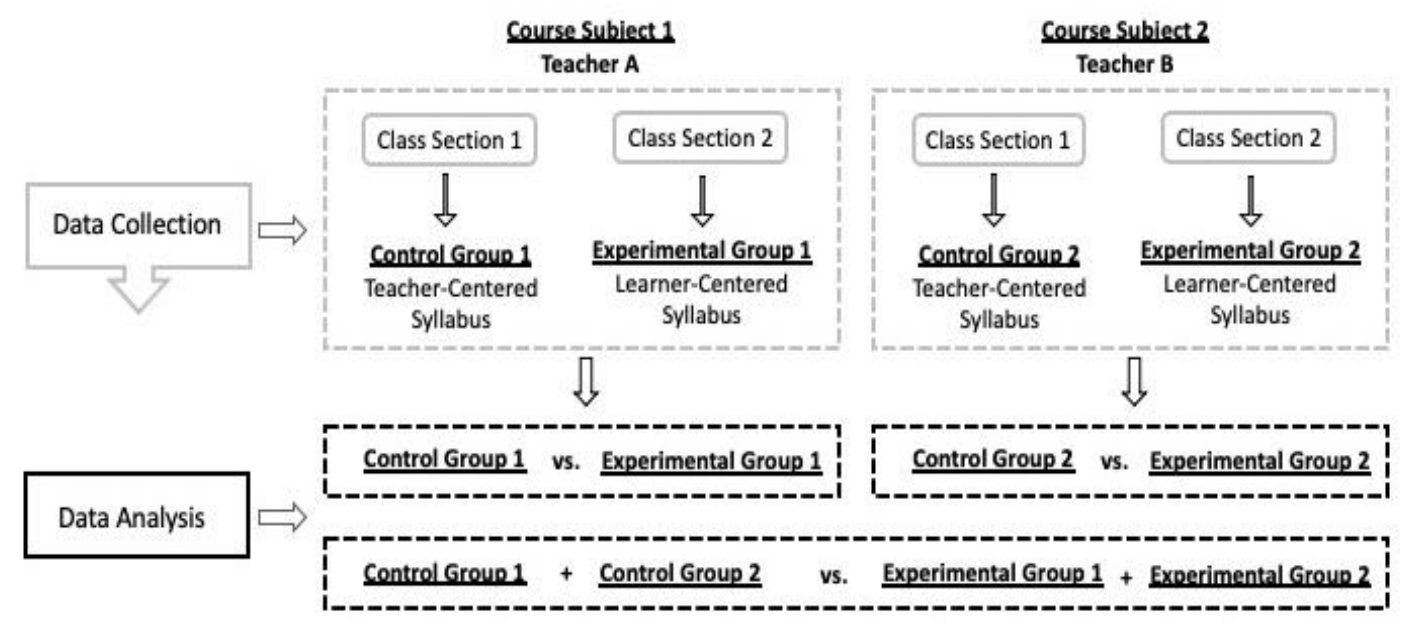

Figure 3. Research method

Standard syllabi for the department in which the classes were taught trend toward teacher-centered methods. The learnercentered syllabi created for this study were the first syllabi within the department to be developed and implemented with a learner-centered focus.

The classes being compared (Preconstruction and Project Management, and Structures of Building-II) were taught by two of the researchers. Each was teaching two sections of the same class for a total of four classes being evaluated. Since two sections of the same class were assigned to both faculty, this provided an opportunity for each faculty to have both a control group and an experimental group. The control group class would use the syllabus adopted by the teachers in previous semesters of the course, and the experimental group class would use the learner-centered syllabus. Students were already assigned to these classes, and the researchers had no control over their assignment.

The students in this research were a mix of construction management and architecture students. There was a total of 121 students in all four sections (106 construction management and 14 architecture students). Students were either juniors or seniors who had a minimum of two years of experience with college classes prior to enrolling in the class considered. Table 2 shows a summary student demographic data.

Table 2. Student Demographic Data

\begin{tabular}{cccccccc}
\hline Sample Group & $\#$ & Male & Female & Junior & Senior & $\begin{array}{c}\text { Construction } \\
\text { Management }\end{array}$ & Architecture \\
\hline $\begin{array}{c}\text { Preconstruction and Project } \\
\text { Management (Learner Centered) }\end{array}$ & 28 & 26 & 2 & 28 & 0 & 28 & 0 \\
$\begin{array}{c}\text { Preconstruction and Project } \\
\text { Management (Teacher Centered) }\end{array}$ & 28 & 26 & 2 & 28 & 0 & 28 & 0 \\
$\begin{array}{c}\text { Structures of Building-II (Learner } \\
\text { Centered) }\end{array}$ & 34 & 33 & 1 & 34 & 0 & 28 & 6 \\
$\begin{array}{c}\text { Structures of Building-II (Teacher } \\
\text { Centered) }\end{array}$ & 31 & 25 & 6 & 31 & 0 & 23 & 8
\end{tabular}

However, to help reduce the limitations associated with lack of random assignment, the sample population was focused on a single construction program, all at the 3000-course level. Including two course sections for each teacher helped control for the teacher differences variable. The syllabus component was anticipated to help control for the teacher differences issue as well. To some extent, differences in teaching approach were part of what was being evaluated in this study because research suggests that syllabus construct was not only a representation of, but also an influencer to teaching approach (Gannon, n.d.). As part of evaluating the effect on teaching approach associated with the syllabi, teacher reflections of the experience were captured. 


\subsection{Syllabi Development}

A syllabus rubric adapted from other published rubrics (Cullen \& Harris, 2009; Richmond et al., 2016, 2019; Universal Design for Learning: A Rubric for Evaluating Your Course Syllabus, n.d.) was used to develop and evaluate the syllabi on the degree of teacher-centeredness vs. learner-centeredness (Figure 4). For the control group, the two teachers used their original syllabi from previous semesters. These served as the teacher-centered syllabi but had to be evaluated using the developed rubric to determine the degree of teacher centeredness. The rubric was also used to develop the learnercentered syllabi that were used in the experimental group.

\begin{tabular}{|c|c|c|c|c|}
\hline \multicolumn{5}{|c|}{ Scoring Rubric for Assessing Learner-Centeredness through Course Syllabi } \\
\hline & \multicolumn{4}{|c|}{ Score } \\
\hline & 1 & 2 & 3 & 4 \\
\hline \multicolumn{5}{|l|}{ Community } \\
\hline Accessibility of teacher & $\begin{array}{c}\text { Available for prescribed number of office hours } \\
\text { only; discourages interaction except in class or } \\
\text { for emergency }\end{array}$ & $\begin{array}{c}\text { Available for prescribed number of office hours; } \\
\text { provides phone and email but discourages } \\
\text { contact }\end{array}$ & $\begin{array}{l}\text { Available for more than prescribed number of } \\
\text { office hours; offers phone, email, fax, home } \\
\text { phone; encourages interaction }\end{array}$ & $\begin{array}{l}\text { Available for multiple office hours, multiple } \\
\text { means of access including phone(s), email, fax; } \\
\text { holds open hours in locations other than office } \\
\text { (e.g. library or union); encourages interaction }\end{array}$ \\
\hline Learning rationale & $\begin{array}{l}\text { No rationale provided for assignments or } \\
\text { activities }\end{array}$ & $\begin{array}{l}\text { Explanation of assignments and activities but } \\
\text { not tied directly to learning outcomes }\end{array}$ & $\begin{array}{l}\text { Rationale provided for assignments and } \\
\text { activities; tied to learning outcomes. }\end{array}$ & $\begin{array}{l}\text { Rationale provided for assignments, activities, } \\
\text { methods, policies and procedures; tied to } \\
\text { learning outcomes }\end{array}$ \\
\hline Collaboration & Collaboration prohibited. & Collaboration discouraged. & $\begin{array}{l}\text { Collaboration incorporated; use of groups for } \\
\text { work and study. }\end{array}$ & $\begin{array}{c}\text { Collaboration required; use of groups for class } \\
\text { work, team projects; encourages students to } \\
\text { learn from one another }\end{array}$ \\
\hline \multicolumn{5}{|l|}{ Power and Control } \\
\hline Teacher's role & $\begin{array}{c}\text { No shared power; authoritarian; rules are } \\
\text { written as directives; numerous penalties; no } \\
\text { flexibility in interpretation; no accommodation } \\
\text { to differences }\end{array}$ & \begin{tabular}{|c|}
$\begin{array}{c}\text { No shared power; while teacher is ultimate } \\
\text { authority, some flexibility is included for policies } \\
\text { and procedures; some accommodation for } \\
\text { differences among students }\end{array}$ \\
\end{tabular} & $\begin{array}{c}\begin{array}{c}\text { Limited shared power; students may be offered } \\
\text { some choice in types of assignments or weight } \\
\text { of assignments or due dates }\end{array} \\
\end{array}$ & $\begin{array}{c}\text { Shared power. Teacher encourages students to } \\
\text { participate in developing policies and procedures } \\
\text { for class as well as input on grading, due dates } \\
\text { and assignments. }\end{array}$ \\
\hline Student's role & $\begin{array}{l}\text { Student is told what he or she is responsible for } \\
\text { learning. }\end{array}$ & \begin{tabular}{|c|}
$\begin{array}{c}\text { Student is told what he or she is responsible for } \\
\text { learning but encouraged to go beyond minimum } \\
\text { to gain reward. }\end{array}$ \\
\end{tabular} & \begin{tabular}{|c|}
$\begin{array}{c}\text { Student is given responsibility for presenting } \\
\text { material to class. Some projects rely on student- } \\
\text { generated knowledge. }\end{array}$ \\
\end{tabular} & $\begin{array}{l}\text { Students take responsibility for bringing } \\
\text { additional knowledge to class via class } \\
\text { discussion or presentation. }\end{array}$ \\
\hline Outside resources & $\begin{array}{l}\text { No outside resources used other than required } \\
\text { textbook. Teacher is primary source of } \\
\text { knowledge. }\end{array}$ & $\begin{array}{l}\text { Reference to outside resources provided but not } \\
\text { required }\end{array}$ & $\begin{array}{l}\text { Outside resources are included with explanation } \\
\text { that students are responsible for learning } \\
\text { outside of the classroom and independent } \\
\text { investigation. }\end{array}$ & $\begin{array}{l}\text { Outside resources are included with explanation } \\
\text { that students are responsible for learning } \\
\text { outside of the classroom and independent } \\
\text { investigation. Students expected to provide } \\
\text { outside resource information for class. }\end{array}$ \\
\hline Syllabus tone & Tone of syllabus is punitive. & $\begin{array}{l}\text { Weighted towards punitive with some reference } \\
\text { that is positive }\end{array}$ & $\begin{array}{l}\text { Balance between punitive and positive, } \\
\text { encouraging, collaborative tone }\end{array}$ & $\begin{array}{c}\text { Tone of syllabus is positive, encourage, and } \\
\text { collaborative with students }\end{array}$ \\
\hline Syllabus focus & $\begin{array}{l}\text { Focus is on policies and procedures. No } \\
\text { discussion of learning or outcomes. }\end{array}$ & $\begin{array}{l}\text { Weighted towards policy and procedures with } \\
\text { some reference to content covered. }\end{array}$ & $\begin{array}{l}\text { Includes course objectives; balance between } \\
\text { policies and procedures and focus on learning }\end{array}$ & $\begin{array}{l}\text { Syllabus weighted towards student learning } \\
\text { outcomes and means of assessment. Policies } \\
\text { are minimal or left to class negotiation. }\end{array}$ \\
\hline \multicolumn{5}{|l|}{ Evaluation/assessment } \\
\hline Grades & $\begin{array}{l}\text { Focus is on losing points; grades used to } \\
\text { penalize. }\end{array}$ & $\begin{array}{l}\text { Emphasizes the accumulation of points; } \\
\text { disassociated from learning performance. }\end{array}$ & $\begin{array}{c}\text { Grades are tied directly to learning outcomes; } \\
\text { students have some options for achieving points. }\end{array}$ & $\begin{array}{l}\text { Grades are tied to learning outcomes; option for } \\
\text { achieving points. Not all work is graded. }\end{array}$ \\
\hline Feedback mechanisms & $\begin{array}{l}\text { Mid-term and final test grades only. Students } \\
\text { not allowed to see or retain copies of tests. }\end{array}$ & $\begin{array}{l}\text { Mid-term and final test grades with minimal } \\
\text { other graded work. Tests not cumulative. } \\
\text { Students may see but not retain copies of tests. }\end{array}$ & $\begin{array}{l}\text { Grades and other feedback are in the form of } \\
\text { non-graded assignments, activities, } \\
\text { opportunities to conference with teacher. }\end{array}$ & $\begin{array}{l}\text { Periodic feedback mechanisms employed for the } \\
\text { purpose of monitoring learning (lecture response } \\
\text { slips, non-graded quizzes, graded quizzes, tests, } \\
\text { papers, SGID or other feedback on learning) }\end{array}$ \\
\hline Evaluation/assessment & Tests (not comprehensive) & Tests, quizzes and other summative evaluation & $\begin{array}{l}\text { Summative and formative evaluation, written } \\
\text { work required }\end{array}$ & $\begin{array}{c}\text { Summative and formative evaluations including } \\
\text { written and oral presentations, group work, self- } \\
\text { evaluation and peer evaluation }\end{array}$ \\
\hline Learning outcomes & No outcomes stated & $\begin{array}{l}\text { Goals for course stated but not in the form of } \\
\text { learning outcomes. }\end{array}$ & Learning outcomes are clearly stated. & $\begin{array}{l}\text { Learning outcomes stated and are tied to } \\
\text { specific assessments. }\end{array}$ \\
\hline Revision/redoing & No rewriting or redoing of assignments allowed. & $\begin{array}{l}\text { Some rewriting or redoing of assignments } \\
\text { allowed but penalized. }\end{array}$ & Rewriting and redoing of assignments allowed. & $\begin{array}{c}\begin{array}{c}\text { Rewriting and redoing of assignments } \\
\text { encouraged. }\end{array} \\
\end{array}$ \\
\hline
\end{tabular}

Figure 4. Syllabi Assessment Rubric

After each teacher created their version of a learner-centered syllabus for their respective classes, they then evaluated their original syllabus to determine the degree of teacher-centeredness. Once this was done, the two syllabi for each class were distributed to the other researchers (three total researchers including two faculty teaching courses) to conduct an independent review using the rubric. After all syllabi were reviewed and scored by all researchers, a meeting was held to evaluate the scoring. Any differences were discussed among the researchers and adjustments made to each syllabus. A summary of these changes is illustrated in Table 3 below. 
Table 3. Summary of Syllabus Changes Incorporated

\begin{tabular}{|c|c|c|}
\hline Syllabus Element & Class A & Class B \\
\hline $\begin{array}{l}\text { Professor Information (Name, } \\
\text { contact info, office hours) }\end{array}$ & $\begin{array}{l}\text { Added: more office hours } \\
\text { times, virtual office hours } \\
\text { option, open meeting sessions } \\
\text { with instructor at times } \\
\text { determined by students, } \\
\text { instructor background \& } \\
\text { qualifications for course }\end{array}$ & $\begin{array}{l}\text { Same as Class A plus: cell } \\
\text { phone number, and an "open } \\
\text { door policy" promoting student } \\
\text { access to instructor outside of } \\
\text { class time }\end{array}$ \\
\hline $\begin{array}{l}\text { Course Information } \\
\text { (Description, location, texts, } \\
\text { topics, course calendar) }\end{array}$ & $\begin{array}{l}\text { Added: Explanation of active } \\
\text { learning classroom approach, } \\
\text { expectations of students \& } \\
\text { teacher during course, } \\
\text { explanation of course } \\
\text { relevance \& importance to } \\
\text { student's professional } \\
\text { preparation, emphasis on } \\
\text { collaboration in course, course } \\
\text { objectives linked to course } \\
\text { assignments \& tests }\end{array}$ & $\begin{array}{l}\text { Same as Class A plus: a } \\
\text { textbook justification } \\
\text { statement about why the } \\
\text { textbook is prescribed and } \\
\text { important, multiple options for } \\
\text { obtaining the textbook at } \\
\text { minimal cost }\end{array}$ \\
\hline $\begin{array}{l}\text { Grading Information (policy, } \\
\text { scale, assignments) }\end{array}$ & \multicolumn{2}{|c|}{$\begin{array}{l}\text { Added: detailed breakdown of course grading, complete list of } \\
\text { course assessments along with descriptions \& examples of } \\
\text { assignments, opportunity to revise assignments }\end{array}$} \\
\hline $\begin{array}{l}\text { Policy Information } \\
\text { (attendance, late work, honor } \\
\text { code, disability) }\end{array}$ & \multicolumn{2}{|c|}{$\begin{array}{l}\text { Included students in determining course policies on absences, } \\
\text { arriving late, late assignments, and makeup work }\end{array}$} \\
\hline
\end{tabular}

The most important factor was to ensure that the two learner-centered syllabi were modified to be at the highest rank on the rubric to demonstrate that they were as close to fully learner-centered as feasible. Results of the scoring are shown in Table 4 below.

Table 4. Scoring Results

\begin{tabular}{lcccc}
\hline \multirow{2}{*}{ Evaluator } & $\begin{array}{c}\text { Teacher- } \\
\text { Centered } \\
\text { Class A }\end{array}$ & $\begin{array}{c}\text { Teacher- } \\
\text { Centered } \\
\text { Class B }\end{array}$ & $\begin{array}{c}\text { Learner- } \\
\text { Centered } \\
\text { Class A }\end{array}$ & $\begin{array}{c}\text { Learner- } \\
\text { Centered } \\
\text { Class B }\end{array}$ \\
\hline Researcher 1 & $1.6 / 4.0$ & $1.7 / 4.0$ & $3.7 / 4.0$ & $3.7 / 4.0$ \\
Researcher 2 & $1.8 / 4.0$ & $2.2 / 4.0$ & $3.5 / 4.0$ & $3.7 / 4.0$ \\
Researcher 3 & $2.5 / 4.0$ & $2.8 / 4.0$ & $3.8 / 4.0$ & $3.8 / 4.0$ \\
Final Score & $2.0 / 4.0$ & $2.3 / 4.0$ & $3.7 / 4.0$ & $3.7 / 4.0$ \\
\hline
\end{tabular}

The syllabi were distributed to the four classes at the beginning of the semester. To eliminate the potential for bias, students were not told about the experiment. The possibility of students in the different classes discovering they had different syllabi was unlikely because it is uncommon in the Auburn University cohort-based program that students in different classes and cohorts interact with each other.

\subsection{Data Collection}

Student perceptions were collected through a Likert-scale survey instrument. The survey was developed to glean understanding about student perceptions associated with the indicated benefits of a learner-centered syllabus. Details of the questionnaire are shown in Table 5. Recognizing the differences in syllabi construct between the control group and experimental group, care was taken to formulate the survey questions with more generality that would apply to both groups. This allowed a better sense of the effective differences while also reducing potential for directionality bias. 
Table 5. Student Survey Questionnaire

\begin{tabular}{|c|c|}
\hline Focus Area & Question/Statement \\
\hline \multirow[t]{9}{*}{ Syllabus } & 1. The syllabus clearly established the expectations for the course. \\
\hline & 2. The syllabus contained a clear focus on student learning in the course. \\
\hline & $\begin{array}{l}\text { 3. The syllabus contained a clear focus on rules and regulations required of students } \\
\text { for the course. }\end{array}$ \\
\hline & $\begin{array}{l}\text { 4. The syllabus structure provided me encouragement to participate in establishing } \\
\text { class policies (like missed assignments). }\end{array}$ \\
\hline & 5. The syllabus made me feel a sense of ownership in the class. \\
\hline & 6. The syllabus helped me form a positive impression of this course. \\
\hline & 7. The syllabus motivated me to excel in the course. \\
\hline & $\begin{array}{l}\text { 8. The information provided in the syllabus for how my learning would be evaluated } \\
\text { was helpful. }\end{array}$ \\
\hline & $\begin{array}{l}\text { 9. The syllabus helped me clearly understand how my grade in the class would be } \\
\text { determined. }\end{array}$ \\
\hline \multirow[t]{4}{*}{ Instructor } & 1. The instructor demonstrated a clear interest for my success in this class. \\
\hline & 2. The instructor made me feel valued as an individual in the class. \\
\hline & 3. The instructor set high expectations for the class. \\
\hline & $\begin{array}{l}\text { 4. The instructor encouraged a class atmosphere where I was comfortable asking } \\
\text { questions. }\end{array}$ \\
\hline \multirow[t]{9}{*}{ Expectations } & 1. The course required more work than average at XXX. \\
\hline & $\begin{array}{l}\text { 2. The course outline provided in the syllabus suggested to me the course would be } \\
\text { rigorous. }\end{array}$ \\
\hline & 3. The assignments included sufficient detail to complete all the work required. \\
\hline & 4. The grading policy for assignments was clear. \\
\hline & 5. The assignments were provided in a manner that supported my style of learning. \\
\hline & $\begin{array}{l}\text { 6. I was encouraged to learn from other students in the class through shared exercises } \\
\text { and group projects more than other courses at XXX. }\end{array}$ \\
\hline & $\begin{array}{l}\text { 7. I was expected to take responsibility for bringing additional knowledge to the } \\
\text { class through discussion or presentation. }\end{array}$ \\
\hline & $\begin{array}{l}\text { 8. The class provided regular feedback through graded and ungraded work that } \\
\text { supported my learning. }\end{array}$ \\
\hline & $\begin{array}{l}\text { 9. I learned as a result of reworking assignments in the class as allowed by the } \\
\text { instructor. }\end{array}$ \\
\hline
\end{tabular}

The survey was deployed through the online survey software, Qualtrics. Students were provided access to the Qualtrics survey by their instructors through a web link in their class course management system, Canvas. To help ensure a high participation rate, students were offered extra credit by the instructors to complete the survey.

Faculty perceptions were captured through journals over the course of the semester and through an end of semester reflection. Data on course grades were collected by the instructors of record for each class at the end of the semester. Students were anonymized by using codes for each student rather than identifiable information. The grades were compiled into a single excel spreadsheet for analysis.

\subsection{Data Analysis}

Student perceptions scored on a Likert scale were analyzed based on mean scores. Seven categories were considered for student perceptions of syllabi while four categories were considered for student perception of instructor in both the learner-centered and teacher-centered classes. Grade differences were first analyzed on the descriptive statistics of mean, minimum, maximum, range, and standard deviation. The statistics were calculated for the control and experimental group for comparison, and number of each letter grade awarded in both groups was reported. 
Beyond the descriptive statistics, an independent samples t-test was conducted to analyze any statistically significant differences between the class mean grades. The null hypothesis $\left(\mathrm{H}_{0}\right)$ was that the difference in class mean grade score was equal to 0 at a $95 \%$ confidence interval. The alternative hypothesis $\left(\mathrm{H}_{\mathrm{a}}\right)$ was that the difference in mean grade scores was not equal to 0 at the $95 \%$ confidence interval. The test was conducted between the two sections of the same course, and between the control groups and experiemental groups. Analyzing the two sections of the same class provides a look at statistically significant differences between the classes while controlling for the teacher variable. Whereas, analyzing the control vs. experimental groups provides a look at the teacher-centered syllabus vs. the learner-centered syllabus without the control of the teacher variable.

The qualitative comments were entered into Excel $^{\odot}$ and analyzed using qualitative coding. By considering both the Likert scale data from the quantitative component of the survey and the qualitative comments, the results have the potential to provide more knowledge than independent results from either the quantitative or qualitative approaches alone (O'Cathain et al., 2010). After inputting the qualitative comments, "triangulation" was used (Erzerberger \& Prein, 1997; Foster, 1997). Data were collected and analyzed separately to produce two sets of findings. The researchers then combined these findings through data triangulation in an effort to gain a more complete picture of the results (Little, 2013). The triangulation was done separately by each author using "perspective triangulation" which further increases quality and validity in a qualitative analysis (Patton, 1999, p. 1193).

\section{Results}

Syllabi from two distinct sections of two construction management courses in the spring of 2020 were considered. In one section of each course, the syllabus was used as written from the previous fall 2019 semester; in the other, the syllabus was modified to approach a learner-centered syllabus as measured by a syllabus rubric. This research compares student perceptions, faculty perceptions, and student grades between the two sections of each class.

\subsection{What Were Student Perceptions of the Learner-Centered Class as Opposed to The Course That Was More Teacher-} Centered?

One hundred and fourteen students responded to both Likert-style and open-ended questions regarding their perceptions of the classes. The first set of Likert-style questions encouraged students to specifically consider the syllabus for the course in which the student was enrolled. Figure 5 below shows student responses for both teacher-centered and learnercentered classes. Only minor mean differences were noted by students between the two types of syllabi.

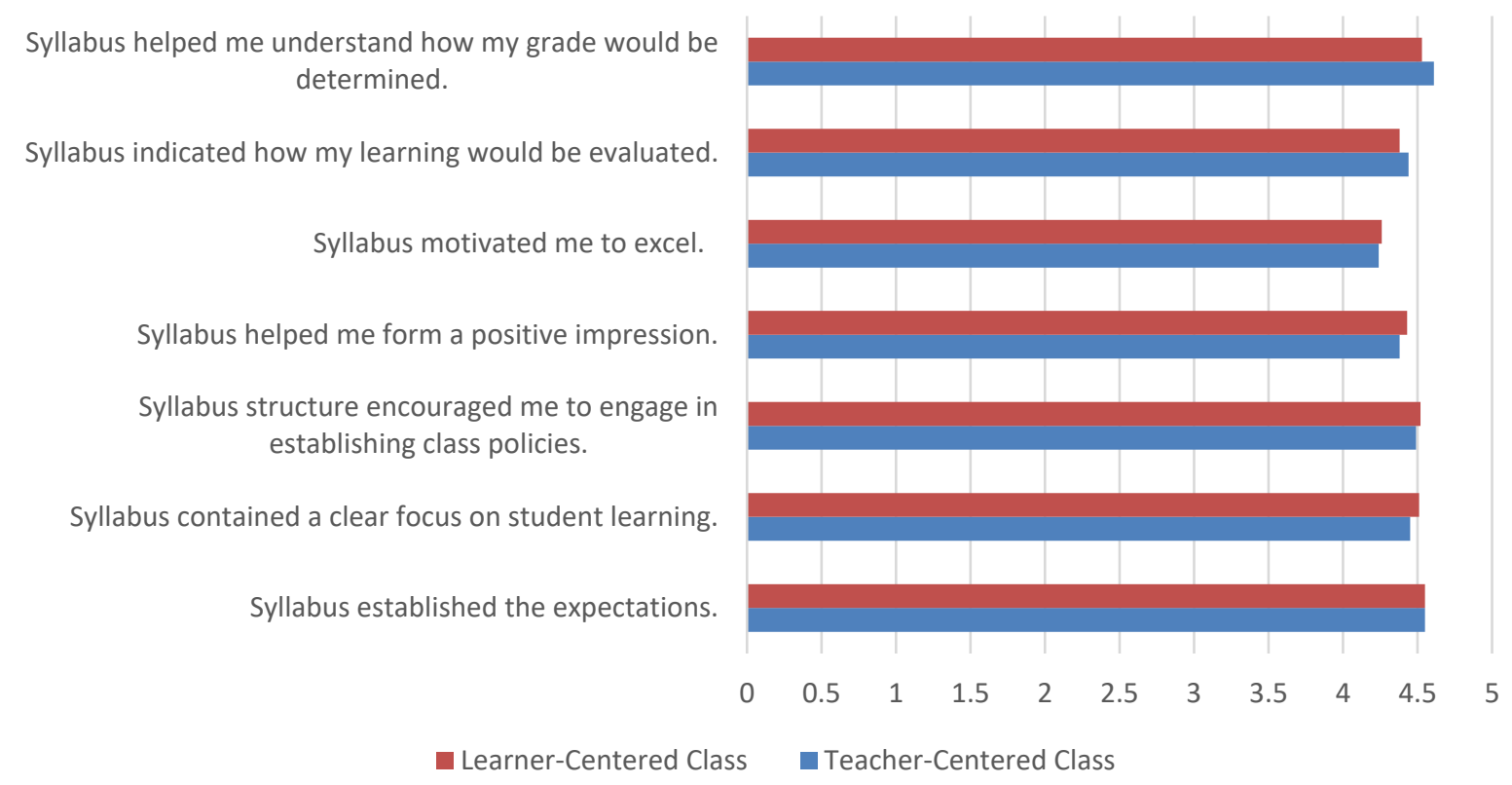

Figure 5. Student perceptions of syllabi in teacher-centered vs. learner-centered classes

Students were also asked to consider the impact of the instructor for both the teacher-centered and learner-centered classes (Figure 6). Again, students' opinions of all statements were remarkably similar between the two classes. 
Instructor encouraged a class atmosphere where I was comfortable asking questions.

Instructor set high expectations.

Instructor made me feel valued as an individual.

Instructor demonstrated a clear interest for my success.

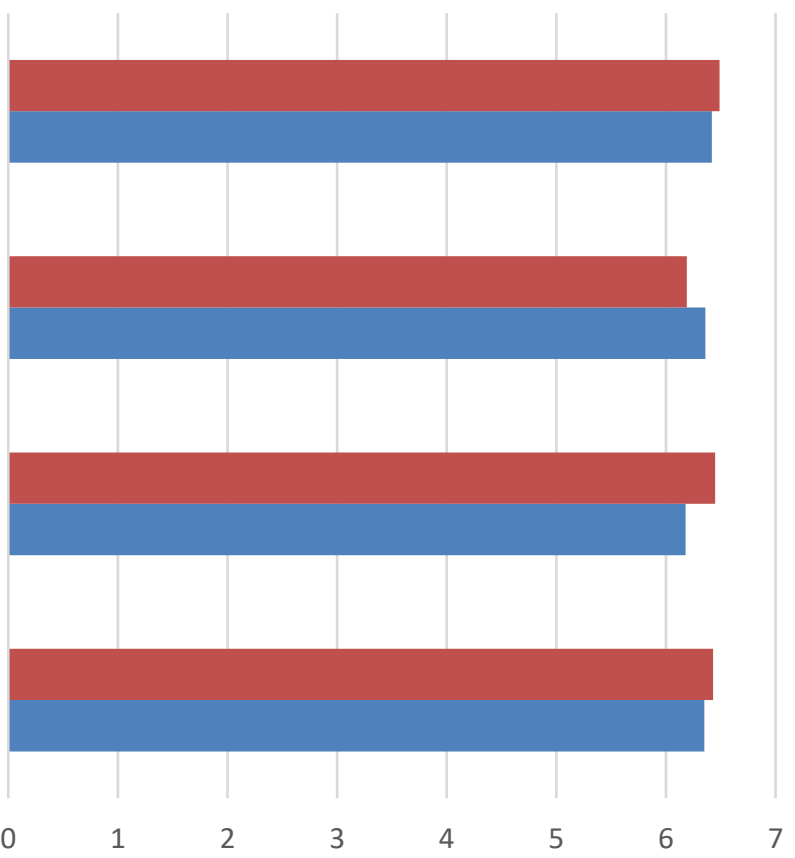

- Learner-Centered Class

- Teacher-Centered Class

Figure 6. Student perceptions of instructor in teacher-centered vs. learner-centered classes

Descriptive responses by students provided additional clarity. In the teacher-centered class, students most often cited the following when responding to what they liked most about the syllabus: "how clear it was" (11 responses); "how scheduled it was" (9 responses); and "how organized it was" (3 responses). Specific comments included "...It was very direct and specific"; "The syllabus was organized and laid out the dates for every assignment. I did not get this from most other classes..."; and "The syllabus was very clear about the expectations of the course."

In the learner-centered classes, the students ( 21 responses) most-liked aspect of the syllabus was the opportunity instructors provided for students to have input on class policies. One student stated, "When suggestions are taken from the class and are implemented within reason into the syllabus, I as a student feel as though my opinion and input is valued from the first day of class. That in turn makes me feel a sense of pride and responsibility within the class." Another stated, "I felt like the teacher really was open to working with the students and figuring out what worked best for students and... what would best educate the students." Other items students appreciated were "the schedule" (6 responses), "the organization" (5 responses), and the "clarity of expectations" (4 responses) set by the syllabus. Again, there were few common responses regarding things students did not like about the syllabus. Three students cited the time required to build the syllabus framework early in the course as a negative.

Quantitative and qualitative data was compared through data triangulation and perspective triangulation with selective results shown in Table 6 . Triangulation confirmed that clear policy and expectations were provided in both the teachercentered and learner-centered classes. Triangulation highlighted the student recognition that participating in development of course policy was valued, and that the syllabus set a tone that gave students a "sense of pride and responsibility". The ability for students to rework assignments in the learner-centered class provided an opportunity for students to recognize the focus on learning throughout the class. 
Table 6. Selective Summary of Triangulation Analysis

\begin{tabular}{|c|c|c|c|c|}
\hline \multirow[b]{2}{*}{ Dimension } & \multicolumn{2}{|c|}{ Teacher-Centered Results } & \multicolumn{2}{|c|}{ Learner-Centered Results } \\
\hline & Quantitative & Qualitative & Quantitative & Qualitative \\
\hline $\begin{array}{c}\text { Clear } \\
\text { Expectations in } \\
\text { Syllabus }\end{array}$ & 4.55 out of 5 & $\begin{array}{l}\text { "how clear it was"; } \\
\text { "schedule made it easy to } \\
\text { follow"; "clear and } \\
\text { concise"; }\end{array}$ & 4.55 out of 5 & $\begin{array}{l}\text { Liked "course schedule"; } \\
\text { "...syllabus was very } \\
\text { clear and concise and set a } \\
\text { tone"; "clear outline" }\end{array}$ \\
\hline $\begin{array}{c}\text { Syllabus } \\
\text { Focused on } \\
\text { Student Learning }\end{array}$ & 4.45 out of 5 & $\begin{array}{l}\text { "the student was very } \\
\text { involved"; "class was } \\
\text { more focused on me and } \\
\text { ensuring that I learn the } \\
\text { information needed in my } \\
\text { career" ( } 45 \text { of } 50 \\
\text { responses) }\end{array}$ & 4.51 out of 5 & $\begin{array}{c}\text { "was more focused on the } \\
\text { needs of the students and } \\
\text { how we can learn" (18 of } \\
46 \text { responses) }\end{array}$ \\
\hline $\begin{array}{c}\text { Syllabus } \\
\text { Included Class } \\
\text { Policy } \\
\text { Participation }\end{array}$ & 4.49 out of 5 & N/A & 4.62 out of 5 & $\begin{array}{l}\text { "enjoyed working with } \\
\text { professor to set } \\
\text { framework for class } \\
\text { delivery" (21 of } 46 \\
\text { responses) }\end{array}$ \\
\hline $\begin{array}{c}\text { Syllabus } \\
\text { Influenced Sense } \\
\text { of Ownership }\end{array}$ & 4.27 out of 5 & N/A & 4.31 out of 5 & $\begin{array}{l}\text { "students were allowed } \\
\text { influence on course } \\
\text { procedures; that in turn } \\
\text { makes you feel a sense of } \\
\text { pride and responsibility" }\end{array}$ \\
\hline $\begin{array}{c}\text { Syllabus } \\
\text { Clarified } \\
\text { Grading Criteria }\end{array}$ & 4.61 out of 5 & $\begin{array}{l}\text { "point system...very } \\
\text { good" }\end{array}$ & 4.53 out of 5 & $\begin{array}{l}\text { Liked "grading } \\
\text { breakdown" }\end{array}$ \\
\hline $\begin{array}{l}\text { Instructor Made } \\
\text { me Feel Valued } \\
\text { in Class }\end{array}$ & 4.33 out of 5 & $\begin{array}{l}\text { "needs of the student } \\
\text { were of top priority, } \\
\text { almost every class started } \\
\text { off with questions we } \\
\text { had" }\end{array}$ & 4.53 out of 5 & $\begin{array}{l}\text { "took time to make sure } \\
\text { we understood the } \\
\text { material"; "feel as though } \\
\text { my opinion and input is } \\
\text { valued" }\end{array}$ \\
\hline $\begin{array}{l}\text { Class Supported } \\
\text { Assignment } \\
\text { Revisions/ } \\
\text { Feedback }\end{array}$ & 3.85 out of 5 & N/A & 4.15 out of 5 & $\begin{array}{l}\text { "different from other } \\
\text { (courses)-allowed us to } \\
\text { resubmit assignments and } \\
\text { receive beneficial } \\
\text { feedback to better } \\
\text { ourselves in learning the } \\
\text { material" }\end{array}$ \\
\hline $\begin{array}{l}\text { Overall Student } \\
\text { Evaluation of } \\
\text { Course }\end{array}$ & $\begin{array}{c}5.84 \text { and } 5.55 \\
\text { out of } 6\end{array}$ & $\begin{array}{l}\text { "comfortable atmosphere } \\
\text { with a teacher that } \\
\text { wanted everybody to } \\
\text { learn"; "felt this class } \\
\text { was considerate to } \\
\text { students, ensuring that I } \\
\text { learn the information } \\
\text { needed in my career" }\end{array}$ & $\begin{array}{c}5.94 \text { and } 5.9 \\
\text { out of } 6\end{array}$ & $\begin{array}{l}\text { "focused on me as a } \\
\text { student"; "class definitely } \\
\text { prioritized the students" }\end{array}$ \\
\hline
\end{tabular}

3.2 What Were Faculty Perceptions of the Learner-Centered Class as Opposed to The Course That Was More TeacherCentered?

The data collection for faculty perceptions was through faculty journals and end of semester reflections. The data analysis revealed some themes in the learner-centered class i.e. student motivation, student pride, student engagement, better understanding of the subject matter, and an overall fun experience for students as well as the faculty. Whereas data analysis 
of the teacher-centered class revealed the following themes: limited student involvement, hardworking students, better collaboration with peers, and very respectful towards class policies.

The faculty felt that the learner-centered class was more engaged during the semester than the teacher-centered class. "The (learner-centered) class demeaner toward me seemed easier; they were not afraid to challenge and debate things. Even if I disagreed with them, the students seemed to understand why, and my disagreement never seemed to stifle them from future questions." One faculty noted that this increased comfort level was challenging early in the semester and mandated tough conversations to control the class dynamic. However, after those conversations, the learner-centered group dynamic improved drastically. Both professors also reported that the teacher-centered class was quieter and less engaging. "It was extremely hard for me to get them to ask questions... I could pretty much count on the fact that there would be no questions (at the end of a lecture)."

The faculty also reported that the learner-centered class seemed more aware of the materials available to them on Canvas (learning management system). Faculty attributed this to the learner-centered syllabi attribute that mandated all items for the class be available from the first day of the class. One faculty stated, "My teacher-centered class had few questions, but when they did, it was often about items that were clearly placed on Canvas." It seemed as if the students in the teachercentered class were less engaged in class and had limited familiarity with the availability of course material.

Finally, both faculty felt that involving students in developing class policies created a feeling of ownership in the learnercentered class. Students were not hesitant to approach faculty outside of class and felt comfortable asking questions. Whereas students in the teacher-centered class hardly approached the respective faculty members outside of class.

\subsection{What Differences May Exist in Grades From Courses With Learner-Centered Syllabi as Opposed to Courses With} More Teacher-Centered Syllabi?

Table 7 shows a summary of the scores for both the control group (teacher-centered syllabus) and the experimental group (learner-centered syllabus). For both classes, there were minimal differences in the mean grades when the control group was compared to the experimental group. Mean scores differed by less than 2.1 points between the groups, and the range of grades experienced were 38.14 for the control group and 36.08 for the experimental group. The 59 students in the controlled group $(M=90.01, S D=5.25)$ as compared to the 62 students in the experimental group $(M=87.91, S D=6.07)$ achieved a difference in scores that was significantly different than zero, $t(119)=2.04, p=.022$.

Table 7. Average Grades in Percentage for Learner-Centered and Teacher-Centered Classes

\begin{tabular}{ccccccccc}
\hline Group & N & Mean & Min & Max & SD & Range & t(119) & p \\
\hline $\begin{array}{c}\text { Controlled Group } \\
\text { (Teacher-Centered Classes) }\end{array}$ & 59 & 90.01 & 57.27 & 95.41 & 5.25 & 38.14 & & \\
$\begin{array}{c}\text { Experimental Group } \\
\text { (Learner-Centered Classes) }\end{array}$ & 62 & 87.91 & 61.11 & 97.19 & 6.07 & 36.08 & & \\
\hline
\end{tabular}

While the data in the table is aggregated for all teacher-centered and learner-centered classes, the mean grade in the classes with teacher-centered syllabi exceeded those for learner-centered classes in both cases (Tables 8 and 9). For course subject 1 , the 31 students in the control group $(M=88.92, S D=6.84)$ vs. the 34 students in the experimental group $(M=87.37$, $S D=6.84)$ had no significant difference in grades, $t(63)=0.91, p=.366$. However, for the subject 2 courses, the 28 students in the control group $(M=91.23, S D=2.08)$ performed significantly better $t(54)=2.60, p=.006$ than the 28 students in the experimental group $(M=88.56, S D=5.02)$.

Table 8. Average Grades in Percentage for Course Subject 1

\begin{tabular}{ccccccc}
\hline Group & $\mathrm{N}_{1}$ & Mean & SD & Range & $\mathrm{t}(63)$ & $\mathrm{p}$ \\
\hline $\begin{array}{c}\text { Controlled Group } \\
\text { (Teacher-Centered Classes) }\end{array}$ & 31 & 88.92 & 6.84 & 38.14 & & \\
$\begin{array}{c}\text { Experimental Group } \\
\text { (Learner-Centered Classes) }\end{array}$ & 34 & 87.37 & 6.84 & 34.26 & & 0.91 \\
\hline
\end{tabular}


Table 9. Average Grades in Percentage for Course Subject 2

\begin{tabular}{ccccccc}
\hline Group & $\mathrm{N}_{2}$ & Mean & SD & Range & $\mathrm{t}(54)$ & $\mathrm{p}$ \\
\hline $\begin{array}{c}\text { Controlled Group } \\
\text { (Teacher-Centered Classes) }\end{array}$ & 28 & 91.23 & 2.08 & 8.37 & & \\
$\begin{array}{c}\text { Experimental Group } \\
\text { (Learner-Centered Classes) }\end{array}$ & 28 & 88.56 & 5.02 & 24.06 & & \\
\hline
\end{tabular}

In addition to the scoring data above, the number of various letter grades were considered for both classes. Most students earned As and Bs in both the control group (57 students) as well as experimental group (58 students). Such grades are typical for students at the junior or senior level in the professional program considered.

\section{Discussion}

This introductory study considered differences in student perceptions, faculty perceptions, and student grades for two sets of construction management courses in the spring of 2020 within the Auburn University construction management program. Both the teacher-centered and learner-centered classes felt that the syllabus set clear expectations and that the classes were generally student focused. The use of learner-centered syllabi motivated student engagement, student understanding of the subject matter, student ownership of the class, and impacted the teacher-student relationship. However, no large difference was found in student grades between learner-centered and teaching-centered syllabi. In addition, results suggest that perception of a class as learner-centered correlates to what happens in the class than what is in the syllabus. In other words, engagement comes from the interactions within the class as opposed to the syllabus. That said, the teachers did indicate they felt the process of constructing their syllabus to have a learner-centered focus made them more aware of learner-centered strategies that likely influenced how they conducted their classes. This suggests the possibility that the real impacts of using a learner-centered syllabus are in the process of creating it rather than the content itself. This makes sense from the perspective that review of the syllabus typically occurs on a single class day representing approximately $2 \%$ of a semester-long class, and it implies that the daily interactions perhaps influence engagement to a greater degree than the syllabus. Further, classes that occur in a smaller, cohort-based major during junior and senior years may have less impact than introductory classes across the university. Often, students in the latter years of their major study become a part of the departmental culture, and this culture may dominate what is stated on the syllabus. In contrast, students in introductory freshmen-level classes where a culture is not established may be more influenced by the syllabus due to the anchoring effect of that occurring early in the semester since no cultural norms have been established.

The qualitative comments of the students with the teacher-centered syllabi differed from the comments of the students with the learner-centered syllabi. Students in the teacher-centered class focused on elements of clarity, organization, and schedule. Students in the learner-centered class had more comments that recognized the value of the ability they had to contribute to class policies and how they had a sense of ownership within the class. One student even spoke about how they felt valued while another spoke about how the process encouraged pride and responsibility as they participated in the class. These responses correlate well with the existing literature from Prior (2018) and DiClementi \& Handelsman (2005) referenced earlier in the paper. The comments indicated that the learner-centered syllabus provided a way for faculty to make an immediate connection with students, to set expectations for the class, and encourage initial engagement in the learning process.

Faculty perceptions suggested stronger student engagement in the learner-centered class, with students being more willing to participate in discussions, challenge concepts and theories, and engage in educated debate with their teacher and classmates. Students also portrayed greater responsibility for items such as reading posted assignments and schedules. In at least one case, the syllabi appeared to lead to an initial student-faculty relationship that challenged the classroom dynamic and mandated additional discussions. The idea that students accepted responsibility for items that contributed to their learning is significant and warrants further study. These initial findings indicate that metacognition, or a student's awareness of willingness to accept responsibility for their own learning, may be motivated throught the use of learnercentered syllabi. If true, student comprehension of material may be easier as the student remains more present and engaged in the learning process.

\subsection{Knowledge Generation}

Prior studies have provided the theoretical foundation of the research questions this study investigated. However, there is no known research that has measured the impact of learner-centered syllabi on student perception, faculty perception and student grades. The authors have attempted to fill this research gap by trying to measure the impact of a learner-centered syllabus vs. a teacher-centered syllabus in an undergraduate construction management program. Minimal differences were seen in the grades; however, both instructors observed that the leaner-centered syllabi produced more empowered, informed, and responsible students. 


\subsection{Limitations and Future Research}

The empirical results of this research must be interpreted with caution, and several limitations were identified:

1) This study experimented with two courses having two sections each, with one being a control group and the other being the experimental group. The same faculty member taught both sections of a course. This may have resulted in same teaching styles between the two groups. For future studies, the researchers plan to investigate the impact of leaner-centered syllabi in multiple courses with different instructors.

2) This study was conducted with two courses having two sections each, with a total sample size of 121 . The sample size is relatively small and may be inadequate to confirm the statistical measurements. More studies need to be performed to further validate the results of this research.

3) The study was conducted in spring 2020 when the classes were transitioned to remote/online learning in mid-semester due to the COVID-19 pandemic. The researchers greatly feel that the transition to remote learning may have influenced the findings of the study.

4) The groups being compared were likely to be dissimilar in some ways due to the lack of random assignment.

5) Differences in teaching methods between teachers from one class to another are an additional limitation. Because of this, any differences that may be indicated between the classes could be due to any of these confounding variables.

Finally, studies examining student perceptions of syllabi with different courses, with different student populations, at different universities are warranted to further qualify the results. Exploring the influence of other variables such as student characteristics, elements of the syllabi on which students focus, whether the syllabus was read, and learning approaches may help further define the type of student the learning-centered syllabus best serves and motivates. In addition, repeating the study with pre- (after syllabi distribution) and post-surveys (end of class) may filter out some of the challenges with the combination of syllabi and the impact of the pedagogy. It is hoped that future related studies will address the limitations of this study.

\subsection{Summary}

The researchers believe that an examination of syllabi on the basis considered here of student perceptions, faculty perceptions, and student grades can serve as a guide for future faculty development initiatives in addition to being a catalyst for discussion of teaching and learning in construction management. This initial research suggests that both teachers and their students may improve the educational experience by employing learner-centered syllabi design. However, more studies using a variety of classes and a variety of teachers are needed to help build results generalizable to the population.

\section{References}

Altrichter, H., Kemmis, S., McTaggart, R., \& Zuber-Skerritt, O. (2002). The concept of action research. The Learning Organization, 9(3), 125-131. https://doi.org/10.1108/09696470210428840

Bain, K. (2004). What the best college teachers do. Harvard University Press.

Baskerville, R. (1997). Distinguishing Action Research from Participative Case Studies. Journal of Systems and Information Technology, 1(1), 25-45. https://doi.org/10.1108/13287269780000733

Becker, A. H., \& Calhoon, S. K. (1999). What introductory psychology students attend to on a course syllabus. Teaching of Psychology, 26(1), 6-11. https://doi.org/10.1207/s15328023top2601_1

Burgstahler, S. E., \& Cory, R. C. (2008). Universal Design in Higher Education: From Principles to Practice. Harvard Education Press.

Cullen, R., \& Harris, M. (2009). Assessing learner-centredness through course syllabi, Assessment \& Evaluation in Higher Education. 34, 1(115-125). https://doi.org/10.1080/02602930801956018

DiClementi, J. D., \& Handelsman, M. M. (2005). Empowering students: Class-generated course rules. Teaching of Psychology, 32, 18-21. https://doi.org/10.1207/s15328023top3201_4

Erzerberger, C., \& Prein, G. (1997). Triangulation: Validity and empirically based hypothesis construction. Quality and Quantity: International Journal of Methodology, 31, 141-154. https://doi.org/10.1023/A:1004249313062

Foster, R. L. (1997). Addressing the epistemology and practical issues in multi method research: A procedure for conceptual triangulation. Advanced Nursing Science, 20, 1-12. https://doi.org/10.1097/00012272-199712000-00002

Frey, B. B. (2020). The SAGE Encyclopedia of Educational Research, Measurement, and Evaluation. https://doi.org/10.4135/9781506326139 
Gannon, K. (n.d.). How to Create an Effective Syllabus. Chronicle of Higher Education. https://www.chronicle.com/interactives/advice-syllabus

Garavalia, L. S., Hummel, J. H., Wiley, L. P., \& Huitt, W. G. (1999). Constructing the course syllabus: Faculty and student perceptions of important syllabus components. Journal on Excellence in College Teaching, 10(1), 5-21.

Harnish, R. J., \& Bridges, K. R. (2011). Effect of syllabus tone: Students' perceptions of instructor and course. Social Psychology Education. https://doi.org/10.1007/s11218-011-9152-4

Hjordis, T. (2018). The Change Room promotes teachers' agency to change their practice. Educational Action Research, 27(2), 248-268. https://doi.org/10.1080/09650792.2018.1436080

Israel, M., Ribuffo, C., \& Smith, S. (2014). Universal Design for Learning: Recommendations for Teacher Preparation and Professional Development (CEEDAR Document No. IC-7). University of Florida. http://ceedar.education.ufl.edu/wp-content/uploads/2014/08/IC-7_FINAL_08-27-14.pdf

John, M. D., Penny, A. B., Meredith, S., Mark, O., \& Susan, H. (2015). Collaborative action research for middle grades improvement. Educational Action Research, 24(2), 194-215. https://doi.org/10.1080/09650792.2015.1058169

Kuh, G. D. (2009). The national survey of student engagement: Conceptual and empirical foundations. New Directions for Institutional Research, 141, 5-20. https://doi.org/10.1002/ir.283

Langley-Turnbaugh, S. J., Blair, M., \& Whitney, J. (2013). Increasing accessibility of college STEM courses through faculty development in UDL. In Universal design in higher education: Promising practices. DO-IT, University of Washington. www.uw.edu/doit/UDHE- promising-practices/college_stem.html

Lightner, R., \& Benander, R. (2018). First impressions: Students and faculty feedback on four styles of syllabi. International Journal of Teaching and Learning in Higher Education, 30(3), 443-453.

Little, T. D. (2013). The Oxford Handbook of Quantitative Methods in Psychology. Oxford University Press. https://doi.org/10.1093/oxfordhb/9780199934874.001.0001

Marlon, S., Mairi, M., Sarah Elaine, E., Barbara, B., \& Michele, J. (2021). Reflection as pedagogy in action research. Educational Action Research, 29(2), 245-258. https://doi.org/10.1080/09650792.2021.1886960

O'Cathain, A., Murphy, E., \& Nicholl, J. (2010). Three techniques for integrating data in mixed methods studies. British Medical Journal, 341. https://doi.org/10.1136/bmi.c4587

Ordem, E. (2021). Participatory action research in a listening-speaking class in second language teaching: towards a critical syllabus. Educational Action Research, 1-17. https://doi.org/10.1080/09650792.2021.1898431

Parkes, J., \& Harris, M. (2002). The Purpose of a Syllabus. Semantic Scholar, 50(2), 55-61. https://doi.org/10.1080/87567550209595875

Patton, M. Q. (1999). Enhancing the quality and credibility of qualitative analysis. Health Services Research, $34(5$ (Pt 2)), 1189-1208.

Prior, J. (2018). Integrating extra credit exercises into a university English-language course: how action research provided a framework to identify a practical problem. Educational Action Research, 26(5), 770-786. https://doi.org/10.1080/09650792.2017.1402687

Richmond, A. S., Morgan, R. K., Slattery, J. M., Mitchell, N. G., \& Cooper, A. G. (2019). Project Syllabus: An Exploratory Study of Learner-Centered Syllabi. Teaching of Psychology. 46(1), 6-15. https://doi.org/10.1177/0098628318816129

Richmond, A. S., Slattery, J., Morgan, R. K., Mitchell, N., \& Becknell, J. (2016). Can a learner-centered syllabus change student's perceptions of student-professor rapport and master teacher behaviors? Scholarship of Teaching and Learning in Psychology, 2, 159-168. https://doi.org/10.1037/st10000066

Saville, B. K., Zinn, T. E., Brown, A. R., \& Marchuk, K. A. (2010). Syllabus detail and students' perceptions of teacher effectiveness. Teaching of Psychology, 37, 186-189. https://doi.org/10.1080/00986283.2010.488523

Syllabus. (n.d.). In Merriam-Webster's collegiate dictionary. http://www.merriam-webster.com/dictionary/onomatopoeia

Tinto, V. (2006). Reseaarch and practic of student retention: What Next? Journal of College Student Retention: Research, Theory, \& Practice, 8, 1-19. https://doi.org/10.2190/4YNU-4TMB-22DJ-AN4W

Universal Design for Learning: A Rubric for Evaluating your Course Syllabus. (n.d.). EnACT PTD: Ensuring Access through Collaboration \& Technology Partnerships, Technology \& Dissemination.

https://www2.ed.gov/about/bdscomm/list/aim/meeting/4-1-2001-teleconference/enact-ptd-overview.pdf 
Weimer, M. (2002). Learner-centered teaching. Josses-Bass, Inc.

Wheeler, L., Palmer, M., \& Aneece, I. (2019). Students' Perceptions of Course Syllabi: The Role of Syllabi in Motivating Students. International Journal for the Scholarship of Teaching and Learning, 13. https://doi.org/10.20429/ijsotl.2019.130307

Wilson, J. H., \& Wilson, S. B. (2007). The First Day of Class Affects Student Motivation: An Experimental Study. Teaching of Psychology, 34(4), 226-230. https://doi.org/10.1080/00986280701700151

Zhao, C. M., \& Kuh, G. D. (2004). Adding value: Learning communities and student engagement. Research in Higher Education, 45, 115-138. https://doi.org/10.1023/B:RIHE.0000015692.88534.de

Zimmer, W. K., \& Keiper, P. (2021). Redesigning curriculum at the higher education level: challenges and successes within a sport management program. Educational Action Research, 29(2), $276-291$. https://doi.org/10.1080/09650792.2020.1727348

\section{Copyrights}

Copyright for this article is retained by the author(s), with first publication rights granted to the journal.

This is an open-access article distributed under the terms and conditions of the Creative Commons Attribution license which permits unrestricted use, distribution, and reproduction in any medium, provided the original work is properly cited. 